\title{
Piperine-Type Amides: Review of the Chemical and Biological Characteristics
}

\author{
Simon Koma Okwute ${ }^{1}$ \& Henry Omoregie Egharevba ${ }^{2}$ \\ ${ }^{1}$ Department of Chemistry, Faculty of Science, University of Abuja, Gwagwalada, F. C. T., Nigeria \\ ${ }^{2}$ National Institute for Pharmaceutical Research and Development (NIPRD), Idu, Industrial Layout, Garki, Abuja, \\ Nigeria \\ Correspondence: Simon Koma Okwute, Department of Chemistry, Faculty of Science, University of Abuja, P.M.B. \\ 117, Gwagwalada, F. C. T., Abuja, Nigeria. Tel: 234-803-595-3929. E-mail: profokwute@yahoo.com
}

Received: June 13, 2013 Accepted: July 20, 2013 Online Published: July 28, 2013

doi:10.5539/ijc.v5n3p99 URL: http://dx.doi.org/10.5539/ijc.v5n3p99

\begin{abstract}
A new group of alkaloids emerged in 1819 following the isolation of piperine from the fruits of Piper nigrum. Since then, a large number of these compounds now referred to as piperine-type alkaloids or alkamides or piperamides have been isolated commonly from species belonging to the genus piper (piperaceae) which have worldwide geographical distribution. As a result of the traditional uses of piper species as spices in foods and in phytomedicines globally a number of their extractives and indeed the constituent amides have been screened for pharmacological properties. The biogenesis of the amides has been investigated and a number of synthetic pathways have been developed to make them readily available for biological studies. It has now been established that piperine and its analogues are potential pesticides and possess a number of medicinal properties. They are regarded as universal enhancers in pesticide and drug formulations. This review enhances our knowledge of these amides and paves way for further work.
\end{abstract}

Keywords: piper species, piperine-type amides, chemical, biological, characteristics

\section{Introduction}

For several decades researchers have investigated the chemical constituents of species belonging to the genus Piper (Okwute, 1978) (Table 1). Prominent among the natural products identified is a group of compounds having the chemical features of piperine, the first known and the most common constituent of the species, and so are classified as piperine-type alkaloids or amides. They are also called alkamides since some of the amides such as pellitorine are purely aliphatic. As a result of the important traditional medicinal uses of members of the genus Piper and the recent interest in their pharmacological properties some reviews have been done on some individual species of the genus such as $P$. nigrum, $P$. guineense and $P$. tuberculatum discussing their potentials as biopesticides for small-scale insect outbreaks and as synergists with pyrethrum (Scott, Jensen, Philogene, \& Amason, 2008). There was also a review on $P$. betel which showed that it contains as many as 30 chemical constituents including allylprocatechol and that it has gastric ulceration healing action as well as anti-inflammatory ability (Vikash et al., 2012). Very recently a review on alkaloids from Piper which focused on the botany, traditional uses, phytochemistry and pharmacology of the genus Piper was reported (Gutierrez, Gonzalez, \& Hoyo-Vadillo, 2012). 
Table 1. Geographical distribution and chemical constituents of some piper species

\begin{tabular}{|c|c|c|}
\hline Piper Species & Distribution & Chemical Constituents \\
\hline Piper auritum $\mathrm{HBK}$ & Mexico & Cepharadiones A and B \\
\hline Piper banskii Mig. & New Queensland & Dillapiole, N-isobutyl-trans-2,trans-4,-octadienamide \\
\hline Piper betle/betel & South East Asia & Piperbetol, hydroxychavicol \\
\hline $\begin{array}{l}\text { Piper brachystachyum } \\
\text { Wall }\end{array}$ & $\begin{array}{l}\text { Northern } \\
\text { America }\end{array}$ & Brachystamides C,D, and E, sesamin, crotepoxide \\
\hline Piper capense & $\begin{array}{l}\text { West, South, and East } \\
\text { Africa }\end{array}$ & Piperine., dihydropiperine \\
\hline Piper chuba Hunter & India, Malaya Islands & Piperine, sylvatine, piperlonguminine \\
\hline Piper cubeba $\mathrm{L}$. & Indonesia & Bicyclosesquiphellandrene \\
\hline $\begin{array}{l}\text { Piper guineense Schum } \\
\text { and Thonn. }\end{array}$ & $\begin{array}{l}\text { West and Central } \\
\text { Africa }\end{array}$ & $\begin{array}{l}\begin{array}{l}\text { Piperine, wisanine, } \\
\text { dihydropiperlonguminine, } \\
\text { piperlonguminine }\end{array} \\
\text { sesamin, }\end{array}$ \\
\hline Piper Hookeri Mig. & India & Neolignans \\
\hline $\begin{array}{l}\text { Piper } \\
\text { kadsura/futokadzura }\end{array}$ & $\begin{array}{l}\text { Southern Japan, } \\
\text { Southmost Korea and } \\
\text { Taiwan }\end{array}$ & $\begin{array}{l}\text { Germacrene, neolignans, piperkadsins } \mathrm{A} \text { and } \mathrm{B} \text {, futoenone } \\
\text { and piperenone }\end{array}$ \\
\hline Piper longun Linn & India & Piperlonguminine \\
\hline Piper methysticum Forst & Pacific Islands & $\begin{array}{l}\text { Methysticin, dihydromethysticin, flavokavain } \mathrm{C} \text {, } \\
\text { dihydrokawain, yangonin }\end{array}$ \\
\hline Piper nepalense Mig & Himalayas & $\begin{array}{l}\text { Piperine, } \\
\text { N-isobutytl-deca-trans-2,trans-4,-dienamide }\end{array}$ \\
\hline Piper nigrum L & $\begin{array}{l}\text { W. Africa, Indonesia, } \\
\text { South America, W. } \\
\text { Indies, S. India }\end{array}$ & $\begin{array}{l}\text { Sesquisabinene, piperylin, cubebin, pipertine, piperoleins A } \\
\text { and B }\end{array}$ \\
\hline $\begin{array}{l}\text { Piper novae-Hollandae } \\
\text { Mig. }\end{array}$ & $\begin{array}{l}\text { New South Wales and } \\
\text { Queensland }\end{array}$ & $\Delta^{\alpha, \beta}$-dihydropiperine \\
\hline $\begin{array}{l}\text { Piper officinarum Cas } \\
\text { DC }\end{array}$ & Indonesia & Methyl piperate, guineensine \\
\hline Piper peepuloides & $\begin{array}{l}\text { Himalayas, W. China, } \\
\text { Burma }\end{array}$ & Pipataline, piperidide dimmers \\
\hline Piper sanctum & Mexico & Cepharadione A \\
\hline Piper sylvaticum & India & Sylvatine, $4^{1}, 7$-dimethoxy-5-hydroxyflavone \\
\hline Piper trichostachyon & India & Trichostachine, trichonine, 1-piperethyl pyrollidine \\
\hline
\end{tabular}


<smiles>O=C(/C=C/C=C/c1ccc2c(c1)OCO2)N1CCCCC1</smiles><smiles>O=C(/C=C\C=C/c1ccc2c(c1)OCO2)N1CCCCC1</smiles><smiles>O=C(/C=C/C=C/C=C/c1ccc2c(c1)OCO2)N1CCCCC1</smiles><smiles>O=C(/C=C/CCc1ccc2c(c1)OCO2)N1CCCCC1</smiles><smiles>O=C(/C=C/C=C/c1ccc2c(c1)OCO2)N1CCCC1</smiles>

Piperiline<smiles>CCCCC/C=C/C=C/C(=O)NCC(C)C</smiles><smiles>CC(C)CNC(=O)/C=C/C=C/CCCCCC/C=C/c1ccc2c(c1)OCO2</smiles><smiles>CC(C)CNC(=O)/C=C/C=C/CCCC/C=C/c1ccc2c(c1)OCO2</smiles><smiles>CC(C)CCC/C=C/CCCCNC(=O)/C=C/C=C/c1ccc2c(c1)OCO2</smiles><smiles>O=C(/C=C/c1ccc2c(c1)OCO2)N1CCCCC1</smiles><smiles>CC(C)CNC(=O)/C=C/C=C/c1ccc2c(c1)OCO2</smiles>

(E)-1-[3',4'-(methylenedioxy)cinnamoyl]piperidine<smiles>CC(C)CNC(=O)/C=C/CCc1ccc2c(c1)OCO2</smiles><smiles>COc1cc2c(cc1/C=C/C=C/C(=O)N1CCCCC1)OCO2</smiles>

$W$ isanine

Figure 1. Piperine-type amides from the genus piper

Apart from piperine, other common members include chavicine, piperettine, piperiline, piperlonguminine, 4,5-dihydropiperlongumine,pellitorine,pipercide,guineensine,sylvatine, $(E)$-1-[3',4'-(methylenedioxy)cinnamoyl] piperidine,wisanine and 4,5-dihydropiperine(Figure 1) (Evans, 2002; Burkill, 1997; Miyakado \& Yoshioka, 1979; Okogun \& Ekong,1974; Addae-Mensah, Torto, \& Baxter, 1976; de Paula, de A Barbosa, Demuner, Pilo-Veloso, \& Picanco, 2000; Gwendoline, Chyi, Mawardi, Khozirah, \& Choon, 2010; Scott et al., 2005). These amides have displayed varying degrees of structural modifications of the aliphatic carbon chain, the terminal basic unit and the substitution pattern on the aromatic nucleus (Figure 1). 
In spite of previous reviews on the genus Piper, there is need for this present review to bring into focus the chemical and biological characteristics of the major constituents of the genus, the piperine-type amides. The biogenesis of the piperine-type amides, the techniques utilised over the years for their isolation, the various approaches to their synthesis and their increasingly important bioactivities will be reviewed in this work. This, we hope, will lead to further chemical and pharmacological investigations of this special group of alkaloids as potential candidates for the development of new drugs and pesticides.

\section{Biogenesis of Piperine-Type Amides}

The piperine-type amides belong to the group of alkaloids in which the basic unit is at the end of an aliphatic chain. The basic unit has commonly been found to be the piperidyl or pyrollidyl or isobutylamino moity. In this review the biogenesis of piperine is used as representative for all the piperine-type amides.

The tertiary amide unit in piperine is incorporated through piperidine. In the biosynthetic pathway, L-lysine is decarboxylated in the presence of pyridoxal phosphate (PLP) to cadaverine, which undergoes oxidative deamination by the enzyme diamine oxidase to an amino aldehyde (Figure 3). The amino aldehyde undergoes cyclization to give the imine, $\Delta^{1}$-piperideine. The imine, $\Delta^{1}$-piperideine, is reduced to piperidine, which reacts with piperoyl-CoA (piperic acid-coenzyme A ester) to give piperine (Figure 2).

The piperoyl-CoA is derived from cinnamoyl-CoA precursor via acetate/shikimic acid pathway (Figure 4), with a chain elongation with acetyl-CoA or malonyl-CoA in a Claisen-type reaction. The resulting keto-ester then undergoes reduction with NADPH, followed by dehydration to piperoyl-CoA (Dewick, 2009; Kato \& Furlan, 2007; Morandim, Bergamo, Kato, Cavalheiro, Bolzani, \& Forlan., 2005).



L-Lysine



(1)

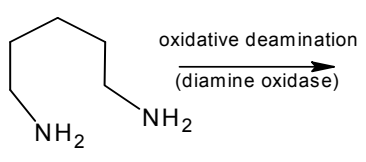

cadaverine

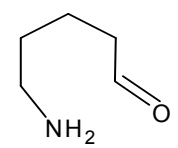

imine formation<smiles>CC(C)(C)C1CCCCN1</smiles>

piperidine $\triangle^{1}$-piperideine<smiles>O=C(/C=C/C=C/c1ccc2c(c1)OCO2)O[Ga]OC(=O)O[Na]</smiles><smiles>O=C(/C=C/C=C/c1ccc2c(c1)OCO2)N1CCCCC1</smiles>

Figure 2. Biosynthesis of piperine in Piper spp.

The shikimic acid pathway begins with the condensation of phosphoenolpyruvic acid (PEP) and D-erythrose-4-phosphate from carbohydrates metabolism. This gives 3-deoxy-D-arabino-heptulosonic acid 7-phosphate (DAHP) via the enzyme DAHP synthase. DAHP cyclises by an $\mathrm{NAD}^{+}$and NADH dependent elimination of phosphoric acid, and through a cascade of enzymic processes and intermediates like 3-dehydroquinic acid and 3-dehydroshikimic acid, to give shikimic acid (Figure 3). The shikimic acid formed is phosphorylated in an energy utilization step into shikimic acid-3-phosphate via shikimate kinase, which further condenses with phosphoenolpyruvate to give 5-enolpyruvylshikimic acid 3-phosphate (EPSP) via EPSP synthase. EPSP is converted to chorismic acid by elimination of phosphoric acid, via the enzyme chorismate synthase, which utilises the reduced form of flavin mononucleotide $\left(\mathrm{FMNH}_{2}\right)$. The formation of chorismic acid marks an important branching point in the biosynthetic pathway. In the first route, anthranilate synthase uses chorismic acid as a substrate to give anthranilic acid, which is a precursor of tryptophan. The synthetic process is controlled by 
feedback inhibition from tryptophan. The second route has the enzyme, chorismate mutase, converting chorismic acid to prephenate, which is the precursor of phenylalanine, tyrosine, phenylpyruvic acid, p-hydroxyphenylpyruvic acid, p-coumaric acid, caffeic acid and p-coumaryl alcohol (Figure 4).

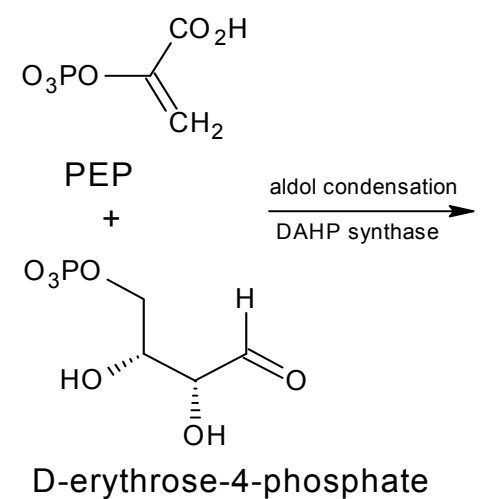<smiles>O=POC[C@@H](O)[C@@H](O)C(O)CC(=O)O</smiles><smiles>C=C(O)[C@H](O)[C@@H](O)CC(=O)O</smiles>

D-erythrose-4-phosphate

\section{DAHP}<smiles>O=C(O)C1=C[C@@H](O)[C@H](O)[C@H](O)C1</smiles>

shikimic acid



3-dehydroshikimic acid<smiles>O=C(O)C1=CC(=O)[C@@H](O)C(O)C1</smiles>

3-dehydroquinic acid<smiles></smiles><smiles>C=C(OC1CC(C(=O)O)=C[C@H](O)[C@H]1O)C(=O)O</smiles>

5-enlpyruvylshikimic acid 3-phosphate<smiles>C=C(OC1C=C(C(=O)O)C=C[C@H]1O)C(=O)O</smiles>

chorismic acid

(EPSP)

Figure 3. The shikimic acid pathway I: biosynthesis of chorismic acid 
<smiles>O=C(O)Cc1ccc(O)cc1</smiles>

4-hydroxyphenylpyruvic acid

<smiles>C=C(OC1C=C(C(=O)O)C=C[C@H]1O)C(=O)O</smiles>

chorismic acid

prephenic acid<smiles>O=C(O)C[C@]1(C(=O)O)C=C[C@@H](O)C=C1</smiles>

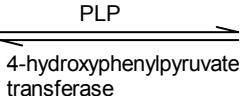<smiles>NC(Cc1ccc(O)cc1)C(=O)O</smiles>

L-tyrosine

<smiles>N[C@@H](C[C@]1(C(=O)O)C=C[C@@H](O)C=C1)C(=O)O</smiles>

L-arogenic acid arogenate
dehydratase prephenate
dehydratase<smiles>O=C(O)Cc1ccccc1</smiles>

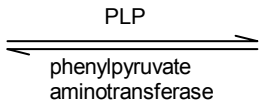

phenylpyruvic acid<smiles>NC(Cc1ccccc1)C(=O)O</smiles>

L-phenylalanine phenylalanine ammonia lyase (PAL)

$\checkmark$<smiles>NC(Cc1ccc(O)cc1)C(=O)O</smiles>

L-tyrosine 4-coumaric acid ( $p$-coumaric acid)<smiles>O=C(O)/C=C/c1ccc(O)cc1</smiles><smiles>O=C(O)/C=C/c1ccccc1</smiles>

cinnamic acid

Figure 4. The shikimic acid pathway II: biosynthesis of cinnamic acid and p-coumaric acid

Phenylalanine generates cinnamic acid via the enzyme phenylalanine ammonia lyase (PAL) by the elimination of ammonia. This is followed by hydroxylation by the enzyme cinnamate 4-hydroxylase in the presence of oxygen and NADPH to give 4-coumaric acid (p-coumaric acid). Similarly, tyrosine yields 4-coumaric acid via the enzyme tyrosine ammonia lyase (TAL). 


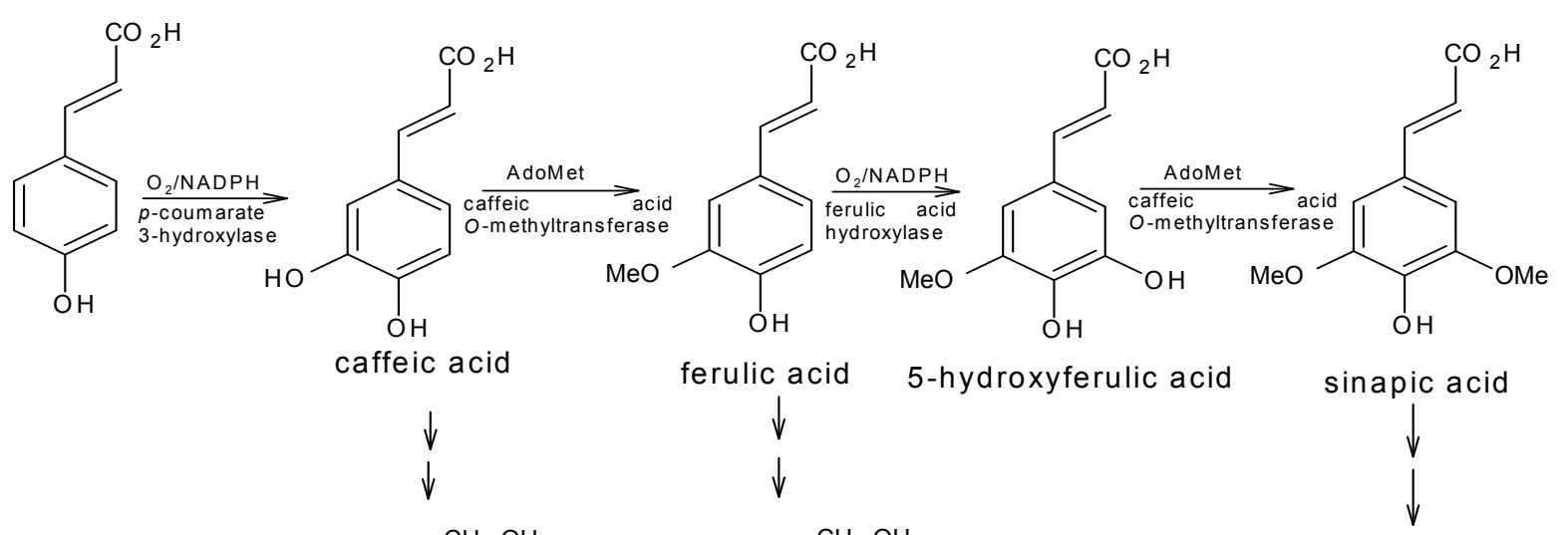<smiles>OC/C=C/c1ccc(O)cc1</smiles>

4-hydroxycinnamyl alcohol<smiles>COc1cc(/C=C/CO)ccc1O</smiles>

coniferyl alcohol $\downarrow \begin{aligned} & p \text {-coumarate } \\ & \vdots \text { CoA ligase }\end{aligned}$<smiles>COc1cc(/C=C/CO)cc(OC)c1O</smiles>

sinapyl alcohol HSCOA<smiles>[R]c1cc(/C=C/C(=O)O)cc([R])c1O</smiles><smiles>[R]c1cc(/C=C/C(=O)[S-](=O)([O-])O)cc([R])c1O</smiles>
aromatic substitution earrangement/<smiles>COC(=O)C(=O)C=Cc1ccc2c(c1)OCO2</smiles><smiles>CO[Sb](=O)(O)C(=O)CC(=O)/C=C/c1ccc2c(c1)OCO2</smiles>

<smiles>CCO</smiles><smiles>O=C(CC(O)C=Cc1ccc2c(c1)OCO2)C(=O)OCCCCO</smiles>

Figure 5. Biosynthesis of piperoyl-CoA from $p$-coumaric acid

Other derivatives of cinnamic acid such as caffeic, ferulic and sinapic acids are obtained by further hydroxylation and methylation reactions, typical of shikimic acid pathway. Methylation is usually catalysed by a broad-specificity methyltransferase enzyme, which utilises $S$-Adenosylmethionine (SAM or AdoMet) as a co-enzyme. Substitution may also occur in the coenzyme A ester form. Reduction of cinnamic acids via coenzyme A esters and aldehydes leads to the corresponding alcohol such as $p$-coumaryl alcohol, coniferyl alcohol and sinapyl alcohol, which are precursors of lignans and lignins (Figure 6). The reduction process is catalyzed by enzyme with a broad-substrate specificity and is NADPH dependent. Modification of the substitution pattern via cyclization of the meta-methoxy group and the para-hydroxyl groups on the cinnamoyl backbone generates the piperoyl moiety (Figure 5) (Dewick, 2009). 
Evidence for the above sequence of biogenetic relationships has been obtained by feeding ${ }^{14} \mathrm{C}$ labelled phenylalanine to cuttings of Salvia splendus and the cinnamic acid derivatives were obtained from the stem of the plant as esters. It was established that the rate of incorporation of ${ }^{14} \mathrm{C}$ into the acid agreed with the above sequence. Also, feeding experiments with each of the acids gave latter members of the sequence, suggesting that hydroxylation or methylation was a sequential process (Harborne, 1964; McCalla \& Neish, 1959). It is apparent therefore that cinnamic acid and its hydroxyl derivatives are the progenetors for $\mathrm{C}_{6}-\mathrm{C}_{3}$ (phenylpropanoid) compounds. Some workers have also proposesd that piperamides, lignans and kavapyrones have their origin from the phenylpropanoid unit, the cinnamic acid-SCoA( Geissman \& Grout,1969). Thus, lignans may be formed by oxidative dimerization of the $\mathrm{C}_{6}-\mathrm{C}_{3}$ unit, while the piperamides may be derived from the extension of the cinnamic 'starter' unit by increments of $\mathrm{C}_{2}$ units (malonyl-SCoA). Similarly, it has been suggested that the kavapyrones arise from the cyclisation of the extended phenylpropanoid unit, a process that has been used to synthesise dl-methysticin (Klohs, Keller, William, Teokes, \& Cronheim, 1959). The co-occurence of lignans and a number of piperine-type amides, including piperine, in extracts of Piper nigrum (Table 1) is suggestive of a common biogenetic route for these compounds (Grewe, Freist, Neumann, \& Kerstein, 1970).

\section{Procedures for Isolation of Piperine-Type Amides}

Hundreds of piperine-type amides have been isolated by a number of researchers. The isolation methods depend on the scale and purpose of the product and operation, as well as the available raw material. Typical methods employed in the isolation involved extraction (by maceration or Soxhlet apparatus) with polar organic solvents such as ethanol, followed by fractionation on a chromatographic column on silica gel, and then recrystallisation from suitable organic solvents such as dichloromethane (de Paula, Barbosa, Demuner, Pilo-Veloso, \& Picanço, 2000). However, most of the piper amides are alkaloidal in nature, and the typical extraction procedure for alkaloids may be employed in the isolation process (Gwendoline et al., 2010; Evans, 2002). The final separation and purification of a mixture of alkaloids may also be done by fractional precipitation or crystallisation of the salts such as oxalates, tartrates or picrates (Evans, 2002). The various recent procedures are discussed below.

\subsection{Extraction as a General Organic Compound}

This method has been employed for the isolation of piperine and piperiline (de Paula et al., 2000). The powered plant material is extracted with ethanol after washing with petroleum ether to remove chlorophyll related pigments. The extract is concentrated under reduced pressure into a dark-brown oily substance and fractionated in a chromatographic column packed with silica gel. A common elution solvent system is hexane/diethyl ether in ratio $1: 2$ by volume. Thin-layer chromatography is then employed to analyse and aggregate related fractions. Piperine and related amides normally crystallize out of the concentrated fractions. The impure fractions could be purified further through recrystallisation from dichloromethane and hexane (de Paula et al., 2000).

\subsection{Extraction as an Alkaloid}

This method has been used by Gwendoline and co-workers to isolate pellitorine, piperine, (E)-1-[3',4'-methylenedioxy)cinnamoyl] piperidine and 2,4-tetradecadienoic acid isobutyl amide (Gwendoline et al., 2010). The dried powered plant is washed with petroleum ether and then subjected to maceration or Soxhlet extraction using ethanol or 5-20\% aqueous alcohol. The extract is concentrated under reduced pressure and then acidified with excess dilute acid (usually 5-10\% aqueous hydrochloric acid). The aqueous solution is filtered to remove un-dissolved materials, which are usually non-alkaloids. The filtrate is basified with excess sodium bicarbonate or concentrated solution of ammonia to about $\mathrm{pH} 10-11$, to liberate the alkaloids. The liberated alkaloids are extracted with an immiscible organic solvent such as chloroform or dichloromethane and separated in a separating funnel. The organic portion is washed thoroughly with distilled water and passed through a desiccant like anhydrous sodium sulphate. The organic extract is concentrated under reduced pressure to yield an oily extract which is separated on a silica gel column into fractions. The fractions are analysed and combined using thin-layer chromatography.

The piperine-type amides crystallise from concentrated fractions and are purified by re-crystallisation (Evans, 2002). Alternatively, the initial basification of the powered plant material is done by moistening with water and mixing with lime. The lime combines with the acids, tannins and other phenolic substances and set the alkaloids free from their salts. The free alkaloids are extracted with an organic solvent such as chloroform, ether or petroleum spirit. The organic extract is concentrated and acidified to obtain the alkaloid from the organic portion. The aqueous layer, which now contains the alkaloid salts, is removed and basified to liberate the alkaloids. The solution is extracted with an immiscible organic solvent such as chloroform and dichloromethane to obtain the free alkaloids (Evans, 2002). 


\subsection{Use of HPTLC and HPLC Techniques}

High performance liquid chromatographic techniques have been effectively used to fractionate, isolate and identify piperine-like compounds from the Piper spp (Kulkarni, Apte, Mary, \& Sane, 2001; Scott et al., 2005). The methods were previously developed to measure the plasma and tissue levels of piperine in animals (Bajad, Singla, \& Bedi, 2002; Sunkara, Mada, \& Vobalaboina, 2001). Scott and co-workers used ethyl acetate as solvent for the extraction of piper amides from plant materials.

In their work the ethyl acetate extract was washed with water and dried with anhydrous magnesium sulphate. It was then concentrated to dryness under reduced pressure and at $60{ }^{\circ} \mathrm{C}$ to obtain the extract of the amides. The piper amides were separated and analysed by HPLC (Scott et al., 2005). For the HPLC analysis, Scott and co-workers used an elution solvent system consisting of acetonitrile and water in a binary gradient, beginning with $30 \%$ acetonitrile, increasing to $70 \%$ at $10 \mathrm{~min}, 90 \%$ at $12 \mathrm{~min}$, and back to $30 \%$ acetonitrile at $15 \mathrm{~min}$. Samples were injected at $2 \mu \mathrm{L}$ and the flow rate was $0.4 \mathrm{~mL} / \mathrm{min}$. A ten-point calibration curve was developed between 1 and 250 $\mu \mathrm{g} / \mathrm{mL}$ for each amide. Piperine and piperlonguminine were measured at $340 \mathrm{~nm}, 4,5$-dihydropiperine and 4,5-dihydropiperlonguminine at $205 \mathrm{~nm}$, and pipercide at $275 \mathrm{~nm}$ (Scott, Puniani, Jensen et al., 2005; Scott, Puniani, Durst et al., 2002). Using this method, Scott was able to analyse extracts of Piper species at a concentration of between 0.1 and $1 \mathrm{mg} / \mathrm{mL}$ ethanol and their principal active compounds identified by LCMS based on five piperamide standards and literature MS values. The method also provided clear separation of the derivatized amides, influenced by lipophilicity and steric effects. Scott and his team also found that saponification of the extracts to remove the less active lipophilic components helps to concentrate the piper amides from the original extract.

High extraction efficiencies have been achieved with near-supercritical carbon dioxide extraction $\left(\mathrm{SCO}_{2}\right)$ (Catchpole, Grey, Perry, Burgess, Redmond, \& Porter, 2003) and with microwave-assisted extraction (MAE) (Raman \& Gaikar, 2002). Supercritical $\mathrm{CO}_{2}$ extraction of pepper requires high pressures and temperatures, but can reduce the amount of solvent required. However, the levels of piperine extracted were about half that obtained with solvents such as acetone (Catchpole et al., 2003). Although MAE is a more rapid extraction technique for piperine compared to conventional extraction techniques, it provides the same level of piperine extraction efficiency and may only be possible for small scale analysis of raw pepper (Raman \& Gaikar, 2002).

\subsection{Saponification Process}

In this method, the crude extract of Piper species is dissolved in methanol and $10 \%$ solution of KOH in methanol (50 mg of KOH in $5 \mathrm{ml}$ of methanol) is added (Scott et al., 2005). The mixture is refluxed for 30 min with a water-cooled condenser. The solution is cooled and $5 \mathrm{ml}$ removed and refluxed for another $30 \mathrm{~min}$. The remaining solvent is evaporated until approximately $80 \%$ of the solvent is removed. $20 \mathrm{ml}$ of diethyl ether and $20 \mathrm{ml}$ of distilled water are added to the evaporated extract and transferred to a separating funnel with mild shaking to reduce foaming. The aqueous layer is removed and kept, and $20 \mathrm{ml}$ of $10 \%$ aqueous solution of $\mathrm{NaOH}$ is added to the ether layer in funnel and shaken. The aqueous extracts are combined and retained. Concentrated $(10 \mathrm{M})$ hydrochloric acid was added in drops to the aqueous layer until the solution was acidic by litmus paper. The aqueous layer is washed with $20 \mathrm{~mL}$ of fresh ether and allowed to separate. The ether fraction is removed, dried with anhydrous $\mathrm{MgSO}_{4}$ and then filtered by suction. The ether layer was evaporated to dryness by rotary evaporator and the extract weighed. The ether layer containing fatty acids was dried with anhydrous $\mathrm{MgSO} 4$ and filtered by suction until dry and weighed. The ether and aqueous fractions were then analyzed for piperamide content by HPLC. The piperine concentration in the aqueous extract was found to double with this method (Scott et al., 2005).

\section{Chemical and Spectral Characterization of Piperine-Type Amides}

\subsection{Chemical Characterization}

Researchers have employed various techniques to characterize piperine-type amides. The approaches included both chemical and spectral characterizations. The approaches that are discussed here commonly apply to most of the amides, especially as the structures are very much modelled after piperine. Generally, the amides undergo alkaline hydrolysis in ethanol to give the basic unit which may be piperidine, pyrollidine or isobutyl amine, and the corresponding acid such as piperic acid or piperylinic acid or guineensic acid, depending on the nature of the carbon chain of the amide (Chatterjee \& Dutta, 1967; Singh, Dhar, \& Atal, 1969). Other chemical manipulations involve catalytic hydrogenation of $\alpha, \beta ; \gamma, \delta$-unsaturated carbon chain or $\mathrm{Zn}-\mathrm{Cu}$ couple reduction of $\Delta^{\alpha, \beta}$-dihydropiperine-type amides to give the perhydro derivatives. The $\mathrm{Zn}$-Cu couple reduction has been used to confirm the presence of conjugation with the amide carbonyl. Oxidation with potassium permanganate or ozonolysis to give piperonal or 3,4- methylenedioxybenzoic acid (piperic acid) or the 2-methoxy derivatives as is 
the case with wisanine, is indicative of the attachment of an unsaturated carbon chain directly to the aromatic ring. The DNPH derivative of piperonal or its analogue is usually prepared to confirm its presence in the products (Ivan \& Torto, 1976).

\subsection{Spectral Characterization}

In addition to chemical degradation and transformation, spectroscopic analyses have been extensively applied in the characterization of piperine-type amides. Most of the amides possess full unsaturation of the hydrocarbon chain or the partly saturated hydrocarbon chain possessing an $\alpha, \beta$-unsaturated amide carbonyl chromophore. In both of the above cases it has been observed that the IR spectrum usually displays absorption bands at 1650 ( $\alpha, \beta$-unsaturated amide carbonyl), 1605 (conjugated trans $\mathrm{CH}=\mathrm{CH}$ ), 1000 (styryl bond) and 925 (methylenedioxy group), while the perhydro- and the $\Delta^{\beta, \gamma}$-dihydropiperine and related amides lack the band at about 1605 (Loder et al., 1969). These IR spectral characteristics are presented in Table 2.

The typical ${ }^{1} \mathrm{H}$ NMR resonance signals, the UV absorption peaks and the MS fragmentation patterns for piperine analogues have been extensively reported and discussed by a number of workers in the past few decades. The ${ }^{1} \mathrm{H}$ NMR signals in the low field region are the most significant and include peaks at 6.25, 6.65-7.65 (ethylenic and aromatic protons), and 5.96 for methylenedioxy protons, as recorded for piperlonguminine, piperine, wisanine, trichostachine and sylvatine, while the peaks in the high field region account for the protons of the aliphatic amino moity (isobutyl, piperidyl) (Okogun, Sodengam, \& Kimbu, 1977; Singh, Dhar, \& Atal, 1969; Banerji \& Ghosh, 1973). The UV absorption peaks include $250,304,378 \mathrm{~nm}$ for piperine-type chromophore irrespective of the aliphatic amino moity. For example piperine and piperlonguminine display identical UV characteristics. However, tetrahydropiperine and analogues have absorptions at 232 and $285 \mathrm{~nm}$ which are close to those of 3 , 4-methylenedioxybenzenes (Banerji \& Ghosh, 1973; Loder, Moorhouse, \& Russell, 1969).

For piperine-type amides, including piperine, sylvatine, trichostachine, sylvatine, piperlonguminine (Figure 1) the mass spectra (MS) are usually characterized by the presence of the following fragment ions $(\mathrm{m} / \mathrm{e}): \mathrm{M}^{+}$(molecular ion), 201 from cleavage at the $\mathrm{C}-\mathrm{N}$ bond of the amide, the 135 mass unit which is suggestive of the formation of methylenedioxy tropylium ion, and is usually the strongest peak (base peak), as well as 173 and 172 representing loss of -CO (28) from m/e 201, followed by loss of a hydrogen atom, respectively (Figure 6) (Chatterjee \& Dutta 1967; Ivan \& Torto, 1976). Thus, differentiation between conjugation and non-conjugation of the aromatic ring with the amide carbonyl function is generally reflected in the IR and UV absorptions and in the MS fragmentation patterns of piperine and related amides (Tables 2-4). This is exemplified by the reported spectral data for guineensine and sylvatine, where the MS peak at m/e 161 is typical of guineensine and related Piper amides, but does not occur for sylvatine and piperine (Tables 2-4, Figure 6) (Okwute, 1978; Banerji \& Ghosh, 1973).

Table 2. IR spectral data for guineensine and sylvatine

\begin{tabular}{cccccccccc}
\hline Compound & \multicolumn{10}{c}{$\left(\mathrm{cm}^{-1}\right)$} \\
\hline Guineensine & 3300 & 1655 & 1630 & 1605 & 1545 & 1000 & 965 & 925 \\
Sylvatine & 3279 & - & - & 1605 & - & 1000 & - & 922 \\
\hline
\end{tabular}

Table 3. UV spectral data for guineensine and sylvatine

\begin{tabular}{cccc}
\hline \multicolumn{2}{c}{ Guineensine } & \multicolumn{2}{c}{ Sylvatine } \\
\hline$\lambda \max ($ Ethanol) & $\log €$ & $\lambda \max ($ Ethanol) & $\log €$ \\
\hline 214 & 4.15 & - & - \\
261 & 4.92 & 259 & 4.69 \\
302 & 3.81 & 304 & 3.97 \\
\hline
\end{tabular}

Table 4. MS fragment mass ions for guineensine and sylvatine

\begin{tabular}{ccccccc}
\hline Compounds & \multicolumn{7}{c}{ Fragment ions ( m/e) } \\
\hline Guineensine & $383(\mathrm{M}+)$ & 248 & 161 & 135 & 131 & 103 \\
Sylvatine & $383(\mathrm{M}+)$ & 201 & 173 & 172 & 171 & \\
\hline
\end{tabular}


(a)

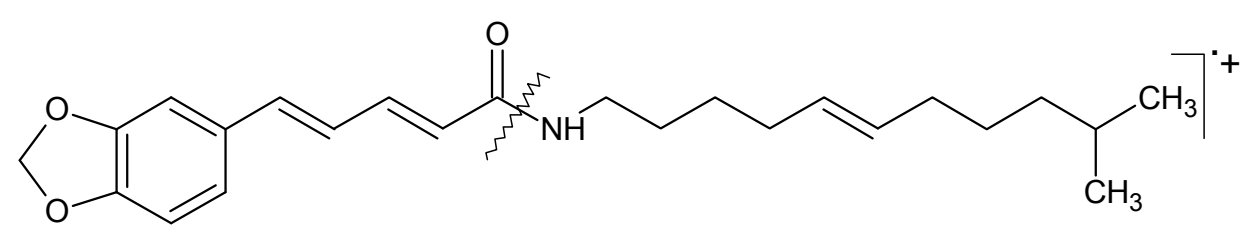

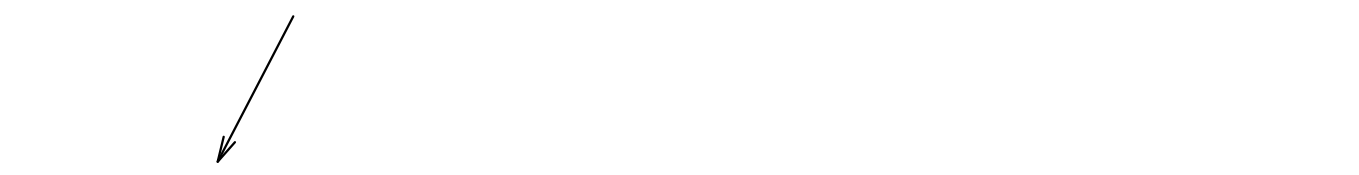



(b)<smiles>[R]C(C)([Te])CC(C)(C)CC=Cc1ccc2c(c1)OCO2</smiles>

Figure 6. MS fragmentations of sylvatine (a) and a guineensine-type amide(b)

\section{Syntheses of Piperine-Type Amides}

\subsection{Synthesis of Piperine and Related Amides}

The structure of piperine was confirmed by synthesis from piperonal prepared from catechol (Reimer-Tiemann reaction), by Ladenburg and colleagues in 1894 (Finar, 1975). In the reaction process, piperonal is condensed with acetaldehyde in the presence of sodium hydroxide (Claisen-Schmidt reaction) to produce a cinnamoyl aldehyde derivative. The product is heated with acetic anhydride in the presence of sodium acetate (Perkin reaction) to yield piperic acid. The piperic acid is converted to its acid chloride by reacting with phosphorus pentachloride, which is then heated with piperidine in benzene solution to yield piperine (Figure 9). Thus, piperine is the piperidine amide of piperic acid (Finar, 1975). 
<smiles>Oc1ccccc1O</smiles>

catechol<smiles>O=Cc1ccc(O)c(O)c1</smiles><smiles>CCCCC[N+](=O)[O-]</smiles><smiles>O=Cc1ccc2c(c1)OCO2</smiles>

piperonal

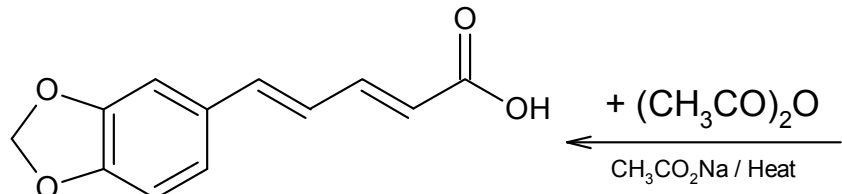

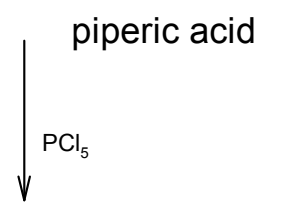<smiles>O=C(Cl)/C=C/C=C/c1ccc2c(c1)OCO2</smiles>

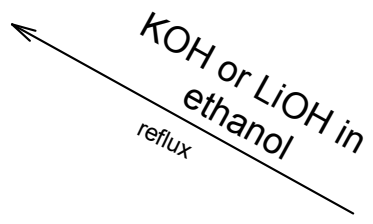<smiles>O=C(/C=C/C=C/c1ccc2c(c1)OCO2)N1CCCCC1</smiles>

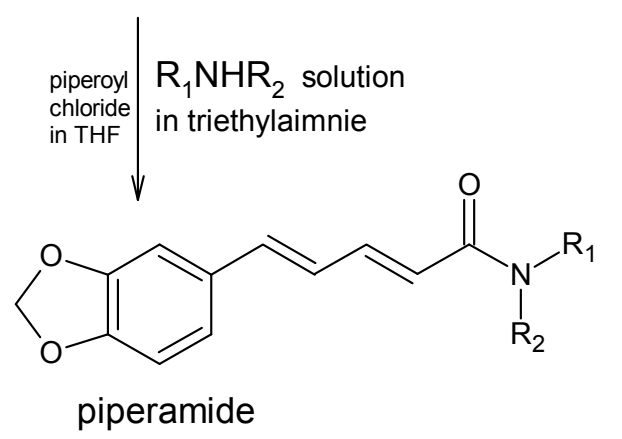

Figure 7. Synthesis of piperine

Thus, some piper amides possessing the piperic acid skeleton have been synthsized from piperic acid as the starting material. Piperic acid can be obtained from piperine by simple alkali hydrolysis in ethanol. Potassium hydroxide or lithium hydroxide monohydrate could be used. The reaction is quenched with concentrated hydrochloric acid after refluxing for several hours (de Paula et al., 2000). The piperic acid formed is converted to its chloride, which is reacted with the appropriate amine to obtain the desired piper amide (Figure 9). de Paula and colleagues used oxalyl chloride, which was added dropwise to a solution of piperic acid in THF. The resultant solution was stirred at room temperature for $6 \mathrm{hr}$, and excess oxalyl chloride removed under reduced pressure. The resultant piperoyl chloride was dissolved in THF and the appropriate solution of amine added along with triethylamine to get the corresponding piperamide (Figure 7) (de Paula et al., 2000). This synthetic procedure is similar to the biosynthetic process, where the amine is incorporated into the piperoyl CoA ester in an amide formation reaction.

\subsection{Total Synthesis of Pipercide}

Miyakado and colleagues in 1979 isolated pipercide from P. nigrum, and reported its remarkable toxicity against the adzuki bean weevil, Callosobruchus chinensis L. (Miyakado et al., 1979). The compound was later synthsized the same year by Miyakado and Yoshiok who established the structure as $(2 E, 4 E$, 
10E)-N-isobutyl-11-(3,4-methylenedioxyphenyl)-2,4,10-undecatrienamide (Miyakado \& Yoshioka, 1979). The closely related amide, piperstachine, was isolated from Piper trichostachyon C. DC. and its structure established as (2E,8E,10E)-N-isobutyl-11-(3,4-methylenedioxyphenyl)-2,8,10-undecatrienamide. The compound was later synthsized by Viswanathan and co-workers, along with its 2E, 4E, 6E-isomer who confirmed the proposed structure for piperstachine (Miyakado \& Yoshioka, 1979; Viswanathan, Balakrishnan, Joshi, \& von Philipsborn, 1975). The synthesis was based on the piperonyl $+\mathrm{C}_{6}+\mathrm{C}_{4}$ construction principle. The reaction process utilized piperonyl alcohol, 1,6-hexanediol and methyl crotonate as starting materials (Figure 8). The $\mathrm{C}_{6}$ unit, 6-(tetrahydro-2'-pyranyloxy)-1-hexanol, was prepared from 1,6-hexanediol and tetrahydropyran, and oxidizing with pyridinium chlorochromate to the corresponding aldehyde. This gave a $95 \%$ yield of the product .To obtain the $\mathrm{C}_{4}$ unit methyl crotonate was brominated with $\mathrm{N}$-bromosuccinimide (NBS) (Wohl-Ziegler reaction) to give methyl 4-bromocrotonate $(92 \%$ yield), which was converted with triethyl phosphite to diethyl-3-methoxycarbonyl-2-propenylphosphonate in 77 \% yield (Davis, Jackman, Siddons, \& Weedon, 1966; Morrison \& Boyd, 2006; Miyakado \& Yoshioka, 1979). The 2,4-dienoate was prepared by condensation of the aldehyde with the phosphonate in the presence of sodium methoxide, whose configurations were predominantly trans at C-2 and exclusively trans at C-4. The protecting group of the 2,4-dienoate was removed by p-toluenesulfonic acid or tosic acid (p-TsOH) in $\mathrm{MeOH}$ to give (2E,4E)-methyl 10-hydroxy-2,4-decadienoate, which was oxidized with pyridinium chlorochromate to (2E,4E)-methyl 10-oxo-2,4-decadienoate. The piperonyl moiety, piperonyl alcohol, was brominated with phosphorus tribromide $\left(\mathrm{PBr}_{3}\right)$ to give piperonyl bromide in quantitative yield, which was converted to 3,4-methylenedioxybenzyl-triphenylphosphonium bromide( $93 \%$ yield) with triphenylphosphine according to the method of Grewe et al. (1970). The phosphonium bromide in benzene was converted with an equimolar amount of n-butyllithium (n-BuLi) in n-hexane solution to the Wittig reagent, which was coupled in situ with an equimolar amount of (2E,4E)-methyl 10-oxo-2,4-decadienoate to give the condensation product in $70 \%$ yield. The ratio of the (E)-isomer to the $(\mathrm{Z})$-isomer at the $\mathrm{C}_{10}$ double bond was about 4: 1 as determined by GLC and NMR spectral analyses.The $\mathrm{E}$ and $\mathrm{Z}$ ester mixture was hydrolyzed (KOH-MeOH) to give the acid. The crude acid was recrystallized twice from benzene to give (2E, 4E, 10E)-11-(3,4-methylenedioxyphenyl)-2,4,10-undecatrienoic acid as fine needles (60\% yield), which was chlorinated with oxalyl chloride. The resultant acid chloride was finally condensed with isobutyl amine yielding (2E, 4E, 10E)-N-isobutyl-11-(3,4-methylenedioxyphenyl)-2,4,10-undecatrienamide (Figure 8).

\subsection{Total Synthesis of Guineensine}

This was achieved using very cheap and readily available laboratory materials such as catechol, oleic acid, crotonic acid and isobutyl amine. 1,2-Methylenedioxybenzene was prepared by heating a mixture of catechol, methylene chloride and sodium hydroxide in a sealed tube at $120^{\circ} \mathrm{C}$ for 17 hours in an oil bath(modified Shorygin et al., 1938). Methyl oleate was subjected to $\mathrm{MnO}_{4} / \mathrm{ZnCl}_{2}$ oxidation to yield azelaic acid monomethyl ester. Treatment of this product with oxalyl chloride and acylation of 1,2-methylenedioxybenzene in the presence of stannic chloride gave the Friedel-Crafts acylation product, methyl $\omega$-piperonoyloctanoate. $\mathrm{NaBH}_{4}$ reduction of the keto-ester, followed by dehydration and hydrolysis gave piperolein B acid which was known (Grewe et al., 1970). $\mathrm{LiAlH}_{4}$ reduction of the acid followed by $\mathrm{CrO}_{3} / \mathrm{Py}$ oxidation gave the corresponding aldehyde which was subjected to Wittig reaction with $\gamma$-triphenylphosphorane methyl crotononate to give $20 \%$ all-trans methyl guineensate. The Wittig reagent was prepared by NBS bromination of methyl crotonate, followed by reaction with triphenylphosphine and dehydrobromination of the phosphonium salt with a solution of NaOMe in methanol. The Wittig reaction product was purified by column chromatography on silica gel and re-crystallisation from methanol. Hydrolysis of the Wittig product with $\mathrm{KOH}$ in methanol gave the acid which on treatment with $\mathrm{SOCl}_{2}$, and then isobutylamine/pyridine, gave the piper amide, guineensine (Figure 9) (Okwute, 1978; Okwute, Okogun, \& Okorie, 1984). 


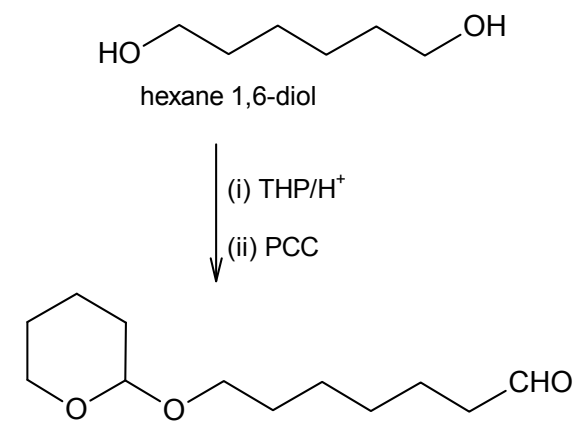

6-(tetrahydro-2'-pyranyloxy)-1-hexanol
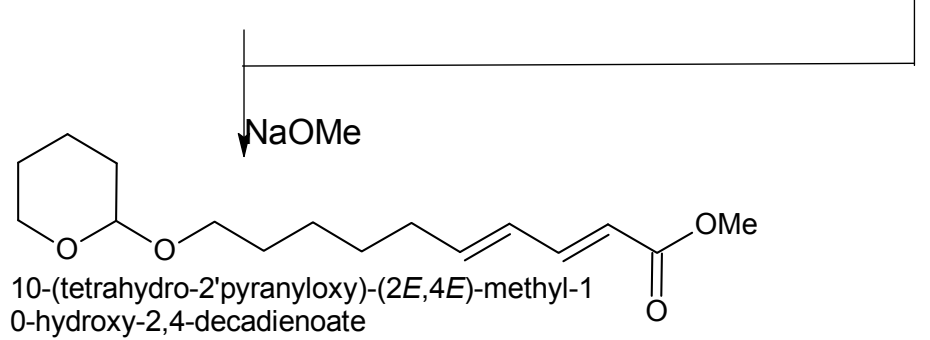

0-hydroxy-2,4-decadienoate<smiles>COC(=O)/C=C/C=C/CCCC[Te][Te]O[Na]</smiles>
enoate<smiles>COC(=O)/C=C/C=C/[C@H](CCCC=O)C(=O)O[Mg]</smiles>
noate<smiles>COC(=O)/C=C/C=C/CCCC/C=C/c1ccc2c(c1)OCO2</smiles>

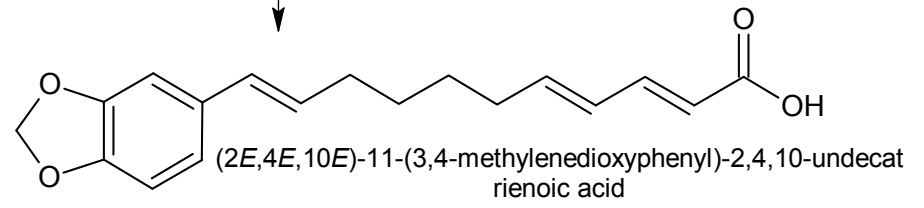

$\downarrow$ (i) oxalyl chloride

$\downarrow$ (ii) isobutylamine<smiles>CC(C)CNC(=O)/C=C/C=C/CCCC/C=C/c1ccc2c(c1)OCO2</smiles>

(2E, 4E, 10E)-N-isobutyl-11-(3,4-methylenedioxyphenyl)-2,4,10-undecatrienamide (pipercide)

Figure 8. Synthesis of pipercide<smiles>OCc1ccc2c(c1)OCO2</smiles>

piperonyl alcohol<smiles></smiles>



3,4-methylenedioxy-benzyltriphenyl-phosph onium bromide<smiles>CCCCCc1ccc2c(c1)OCO2</smiles>

piperonylphosphorane 
<smiles>COC(=O)CCCCCCCC(=O)c1ccc2c(c1)OCO2</smiles>

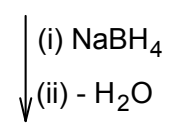<smiles>COC(=O)CCCCCC/C=C/c1ccc2c(c1)OCO2</smiles><smiles>COC(=O)/C=C/C=C/CCCCCC/C=C/c1ccc2c(c1)OCO2</smiles>

(i) Methanol/ $/ \mathrm{OH}^{-}$

(ii) $\mathrm{SOCl}_{2}$<smiles>O=C(Cl)/C=C/C=C/CCCCCC/C=C/c1ccc2c(c1)OCO2</smiles><smiles>CC(C)CNC(=O)/C=C/C=C/CCCCCC/C=C/c1ccc2c(c1)OCO2</smiles>

Figure 9. Synthesis of guineensine 


\section{Biological Characteristics of Piperine-Type Amides}

The observed biological activities of the species of the genus Piper in the past decades led to several investigations to confirm the activities and isolate their active principles. These bioactivities are in many diverse ways, but generally in two important areas: (1) as pesticides for agricultural uses, and (2) as medicines to fight infections, tumours/inflammations, obesity/diabetes, depression and other human and animal physiological disorders.

\subsection{Pesticidal Activity}

The insecticidal properties of black pepper (Piper nigrum L.) extracts were first observed in 1924 (Scott \& McKibben, 1978). These extracts were reported to exhibit insecticidal effect against several insects, including the mosquito, Culex pipiens pallens, the rice weevil, Sitophilus oryzae L, the cotton boll weevil, Anthonomus grandis Boheman, the cowpea weevil, Callosobruchus chinensis L, the stored bean weevil, Zabrotes subfasciatus Boheman, and the housefly, Musca domestica L. They also exhibited repellent action against the adult corn earworm, Heliothis zea Boddie (Scott \& MicKibben, 1978; Su, 1977; Flores, Sampaio, Marques, \& Costa, 1993; Su, 1981; Park, 2012). The investigation of the chemical constituents of black pepper and other Piperaceae species led to the identication of over 140 lipophilic amides as the major type of metabolites that are responsible for the insecticidal properties of these plants (Parmar et al., 1997; Ahn et al., 1992; Okwute, 1978, 1992).

Prominent among the piper amides are piperine, piperiline, pellitorine, pipercide and guineensine (Figure 1).The insecticidal activity of piperine, which is the major constituent found in most Piper species, and some other piper amides has been well established by various workers. Piperine has been found to be more toxic to the domestic fly than piretro (de Paula et al., 2000; Miyakado, Nakayama, \& Ohno, 1989; Synerholm, Hartzell, \& Arthur, 1945). de Paula and colleagues also tested piperine against $A$. monuste orseis, A. obtectus, B. brassicae, C. cumulans, and $P$. exigua. The compound exhibited $95 \%$ mortality against $A$. monuste orseis after $48 \mathrm{hrs}$ at a dose concentration of $40 \mu \mathrm{g} / \mathrm{mg}$ larvae, $25 \%$ mortality against $A$. obtectus after $48 \mathrm{hrs}$ at a dose concentration of $2.61 \mu \mathrm{g} / \mathrm{mg}$ insect, $30 \%$ mortality against $B$. brassicae after $6 \mathrm{hrs}$ at a dose concentration of $31.25 \mu \mathrm{g} / \mathrm{mg}$ insect, $7.5 \%$ mortality against $C$ cumulans after $12 \mathrm{hrs}$ at a concentration of $1.19 \mu \mathrm{g} / \mathrm{mg}$ insect, and $8.6 \%$ mortality against $P$ exigua after $6 \mathrm{hrs}$ at a concentration of $2.63 \mu \mathrm{g} / \mathrm{mg}$ insect (de Paula et al., 2000). de Paula and colleagues synthesized and tested other derivatives of piperine in the same study and found that though the test insects/larvae were sensitive to most of the derivatives, the differences in activities and specificity of the synthesized compounds were widely varied and did not depend on the similarity in structure. However, several other reports by different workers have shown that the most active piper amides are the N-isobutyl substituted (Blade, 1990; Elliott, Famham, Janes, Johnson, \& Pulman, 1987; Miyakado, Nakayama, Inoue, Hatakoshi, \& Ohno, 1985). In the same study piperiline was found to exhibit $40 \%$ mortality against $A$. monuste orseis after $6 \mathrm{hrs}$ at a dose concentration of $40 \mu \mathrm{g} / \mathrm{mg}$ larvae, $10 \%$ mortality against $A$. obtectus after $6 \mathrm{hrs}$ at a dose concentration of $2.61 \mu \mathrm{g} / \mathrm{mg}$ insect, $82.5 \%$ mortality against $B$. brassicae after $48 \mathrm{hrs}$ at a dose concentration of $31.25 \mu \mathrm{g} / \mathrm{mg}$ insect, $22.5 \%$ mortality against $C$. cumulans after $6 \mathrm{hrs}$ at a concentration of $1.19 \mu \mathrm{g} / \mathrm{mg}$ insect, and $13.2 \%$ mortality against $P$. exigua after $12 \mathrm{hrs}$ at a concentration of 2.63 $\mu \mathrm{g} / \mathrm{mg}$ insect (de Paula et al., 2000). The results of the study showed that piperine and piperiline may have a synergistic effect when combined as an insecticide. However, piperiline has been reported to have no toxic effect against Toxocara canis (de Paula et al., 2000; Kiuchi, Nakamura, Tsuda, Kondo, \& Yoshimura, 1988). Piperine has also been found to be toxic to Callosobruchus chinensis L. (Dev \& Koul, 1997).

Insecticidal bioassay studies of the fruit extracts of $P$. guineense using cage experiments have revealed that both the petroleum ether and chloroform extracts were active against the garden insect, Zonocerus variegatus (L) (grasshopper). The powdered fruit has also been reported to give protection to cowpea seeds, Vigna unguiculata (L) Walp against the adults of the cowpea bruchid, Callosobruchus maculatus (F) causing a mortality rate of $96 \%$ in 48 hours. In these studies a piperine-type amide, guineensine, was found to be the insecticidal agent, and piperine, as the synergist in the crude extract (Table 5) (Ogobegwu, 1973; Okogun \& Ekong, 1974; Ivbijaro \& Agbaje, 1986; Okwute, 1992). 
Table 5. Comparative insecticidal activities in 1 hour of extractives from fruit of Piper guineense against the garden insect, Zonocerus variegatus

\begin{tabular}{ccc}
\hline Sample & Concentration \% & \% Insects Dead or Moribund \\
\hline Petroleum ether extract & 0.1 & 20.0 \\
Chloroform extract & 0.1 & 30.0 \\
Guineensine & 0.05 & 35.0 \\
Piperine & 0.5 & 50.0 \\
\hline
\end{tabular}

Dyer and co-workers also reported the antifeedant activity of cenocladamide, desmethylpiplartine and piplartine (Figure 10) isolated from the Costa Rican species, P. cenocladum, on the herbivores, Paraponera. clavata, Spodoptera frugiperda and Atta cephalotes, and found the amides to act synergistically as antifeedant (Dyer et al., 2003). Pipercide and pellitorine have also been found to be toxic to Callosobruchus chinensis L. at 0.15 and 2 mg/male Callosobruchus chinensis L., respectively (Dev \& Koul, 1997). Batista-Pereira and colleagues recently established the insecticidal potency of some synthetic cinnamoyl amides as comparable to that of piperine (Batista-Pereira et al., 2006)<smiles>COc1cc(/C=C/C(=O)N2CCC=CC2=O)cc(OC)c1OC</smiles>

Piplartine<smiles>CC(C)CNC(=O)/C=C/c1ccc2c(c1)OCO2</smiles>

N-isobutyl-[3',4'-(methylenedioxy)]cinnamoylamide<smiles>O=C(/C=C/C=C/CCc1ccc2c(c1)OCO2)N1CCCCC1</smiles>

(from P. tuberculatum in Brazil)<smiles>COc1cc(/C=C/C(=O)N2C=CC(=O)CC2)cc(OC)c1O</smiles>

Cenocladamide

(from $P$. cenocladum)<smiles>COc1cc(/C=C/C(=O)N2CCC=CC2=O)cc(OC)c1O</smiles>

4'-desmethylpiplartine

(from $P$. cenocladum)<smiles>CCCCOCCOCCOCc1cc2c(cc1CCC)OCO2</smiles>

Piperonyl Butoxide<smiles>C=CCc1cc2c(c(OC)c1OC)OCO2</smiles>

Dillapiol

Figure 10. Methylenedioxyphenyl (MDP) insecticide synergists 


\subsection{Medicinal Properties}

Though, most of the piper amides have been reported to be insecticidal or insecticide synergists, some have been found to possess antifungal, antimicrobial and anti-tumour activities (Kato \& Furlan, 2007; Gwendoline et al., 2010). Piplartine (Figure 10), an amide isolated from the Piper species, P. tuberculatum, which is predominant in Brazil, has been found to display significant activity against KB (nasopharyngeal carcinoma), P-388 (lymphocytic leukaemia), A-549 (lung carcinoma) and HT-29 (colon carcinoma) cell lines, all in cell culture systems (Bezerra et al., 2005). In a recent study by Bezerra and colleagues, piplartine and piperine were tested for their cytotoxicity on the brine shrimp lethality assay, sea urchin eggs development, 3-(4,5-dimethyl-2-thiazolyl)-2,5-diphenyl-2H-tetrazolium bromide (MTT) assay using tumor cell lines and lytic activity on mouse erythrocytes. Piperine showed higher toxicity in brine shrimp (DL50 $=2.8 \mathrm{~d} 0.3 \mu \mathrm{g} / \mathrm{ml}$ ) than piplartine (DL50 = 32.3 d $3.4 \mu \mathrm{g} / \mathrm{ml}$ ). Both piplartine and piperine inhibited the sea urchin eggs development during all phases examined, but piplartine was more potent than piperine. In the MTT assay, piplartine was the most active with $\mathrm{IC}_{50}$ values in the range of 0.7 to $1.7 \mu \mathrm{g} / \mathrm{ml}$. None of the tested substances induced haemolysis of mouse erythrocytes, suggesting that the cytotoxicity of piplartine and piperine was not related to membrane damage. The cis-isomer and the 2, 3-dihydro isomers of piplartine as well as the piper amide, $\mathrm{N}$-isobutyl-[3'4'-(methylenedioxy)]-cinnamoylamide, have been isolated from P. tuberculatum (Kato \& Furlan, 2007; Bezerra et al., 2005).

A mixture of piperdardine (Figure 10) and piperine in equal amounts has been found to lower blood pressure (hypotension) and lower the heart rate (bradycardia) in non-anesthetized rats (de Araújo-Júnior et al., 2011). Intravenous injection of the combined amides at doses of $1.5,2.5$ and $5.0 \mathrm{mg} / \mathrm{kg}$, in normotensive rats reduced the diastolic blood pressure (DBP) and heart hate (HR) in a dose dependent manner. This effect was affected in rats treated with methysergide $(5 \mathrm{mg} / \mathrm{Kg}$, i.v), a nonspecific serotonergic antagonist. In anesthetized and ventilated animals, PTPP lowered the DBP and the HR in a significant manner (de Araújo-Júnior et al., 2011).

One of the most investigated Piper ssp. in the past decade for its medicinal activities and which contains piperine as the active component is $P$. Longum (long pepper). For example, it has potential as a therapy for the treatment of obesity and Type 2 diabetes (Lee et al., 2006), caecal amoebiasis (N. Sawangjaroen, K. Sawangjaroen, \& Poonpanang, 2004), possesses immunomodulatory and anti-tumour activities (Sunila \& Kuttan, 2003), has potential as a female contraceptive (Sharma et al., 2001), and has antiulcerogenic effects (Agrawal, Rao, Sairam, Joshi, \& Goel, 2001). Piperine has also been reported to display central nervous system depression, analgesic, antipyretic, anti-inflammatory, and antioxidant activities (Parmar et al., 1997; Mittal \& Gupta, 2000). It also prevents liver and stomach carcinogenesis induced by chemical carcinogens (Khajuria, Thusu, Zutshi, \& Bedi, 1998). Piperine has recently been reported to inhibit lung metastasis induced B16F-10 melanoma cells in mice, to be cytotoxic in the brine shrimp assay, to stimulate melanocyte proliferation and melanocyte differentiation, to protect Swiss albino mice from benzo[ $\alpha]$ pyrene-induced lung carcinogenesis, and to possess immunomodulatory and antitumour activities (Bezerra et al., 2005). In an in vitro study, Scott and colleagues found that piperine inhibits the enzyme polysubstrate monoxygenase (PSMO), which is a detoxification enzyme, and Leptinotarsa decemlineata (Say) which feeds on potato plants, but was to degrade by $80 \%$ in the treated potato Solanum tuberosum L. (Solanaceae) plants under sunlight after 3 hrs. The PSMO inhibitory activity of piperine was demonstrated to be almost as effective as piperonyl butoxide (PBO) against multi-resistant insects

The average $\mathrm{IC}_{50}$ for 2-methoxyresorufin O-demethylation (MROD) enzyme assays was determined at $1.2 \mu \mathrm{M}$ piperine ( $1 \mathrm{mM}$ dose) compared to less than $0.43 \mu \mathrm{M}$ for piperonyl butoxide. Dillapiol at $0.43 \mu \mathrm{M}$ did not affect MROD activity with the LPR housefly microsomes. Both PBO and dillapiol (Figure 14) are methylenedioxyphenyl (MDP) molecules but do not contain the neurotoxic amide function of piper amides, and are insecticide synergists. Though black pepper is considered a food grade spice and categorized by the U.S. F.D.A. as "Generally Regarded as Safe" or GRAS (CITE: 21CFR182.10), it has also been reported to be neurotoxic (Scott et al., 2003). In terms of the health risks, piperine is the only piper amide thus far listed on the E.P.A.s Toxic Substances Control Act (TSCA) inventory. It is a category R 22, (harmful if swallowed), and has precautions S22-25, (not inhaling the dust, fumes, or vapours, as well as avoiding contact with skin and eyes)(Scott et al., 2003). The $\mathrm{LD}_{50}$ s for piperine in male adult mice were determined to be 330 and $200 \mathrm{mg} / \mathrm{kg}$ for single intra gastric (i.g.) or subcutaneous (s.c.) injections, respectively, and in subacute studies piperine at $100 \mathrm{mg} / \mathrm{kg}$ body weight /day for 7 days was not toxic (Piyachaturawat, Glinsukon, \& Toskulkao, 1983). Piperine had previously been shown to inhibit the activities of other detoxification enzymes in mammals: arylhydrocarbon hydroxylase (AHH) and 7-ethoxycoumarin deethylase (7ECDE) activities in rat lung microsomes (Reen \& Singh, 1991), 7-methoxycoumarin demethylase (MOCD) activity in hepatoma cells with and without phenobarbitol, a substrate that induces monooxygenase activity (Singh \& Reen, 1994), and the 
major drug-metabolizing enzyme CYP3A4 (Bhardwaj et al., 2002). However, further mammalian studies showed that piperine can also induce phases I and II PSMO enzymes such as glutathione S-transferase (GST), cytochrome b5, cytochrome P-450, acid-soluble sulfhydryl (-SH), and malondialdehyde (MDA) levels (Singh \& Rao, 1993). Another bioassay indicated that metabolism of methoxyresorufin to resorufin is inhibited in vitro, but this is yet to be confirmed in vivo (Scott et al., 2003). Pellitorine has been found to show strong cytotoxic activities against HL60 (Human promyelocytic leukemia cells) and MCT-7 cell lines (Gwendoline et al., 2010). Gwendoline and co-workers compared the cytotoxicity of pellitorine and the petroleum ether extract of $P$. nigrum against $\mathrm{HL} 60$ cell line and found pellitorine to have a comparable $\mathrm{IC}_{50}$ value of $13.0 \mu \mathrm{g} / \mathrm{mL}$ against 9.8 $\mu \mathrm{g} / \mathrm{mL}$ exhibited by the extract. However in a study against MCF-7 (breast cancer) cell line, pellitorine gave a much lower $\mathrm{IC}_{50}$ value of $1.8 \mu \mathrm{g} / \mathrm{mL}$. Hence pellitorine could be a potential anti-cancer hit compound.

Structure-activity relationships (SARs) studies among the piper amides have suggested that for activity the lipophilic chain must contain at least four carbons and that a conjugated bond, adjacent to the amide carbonyl is necessary for binding and that the amine part must be bulky (Pedersen et al., 2006). This makes piperine a model compound for the bioactive amides. In line with this finding it has been found that activity among the piperidine amides increases with increasing substitution on the piperidine ring carbons, with ethyl substituted being more active than the methyl analogues (Pridgeon et al., 2007). In most of the above activities piperine has been implicated particularly in the crude extracts. Thus, piperine and some of its derivatives are regarded as universal enhancers, potentiating the bioactivities of other extractives (Khajuria, Thusu, \& Zutshi, 2002) and account for the traditional medicinal uses of Piper spp.

\section{Conclusion}

The genus Piper has one of the largest membership in the plant kingdom and one of the most widely distributed globally, covering all the continents, but most commonly found in Asia, North and South America, and Tropical Africa (West Africa). A number of the species have been scientifically investigated for their chemical constituents and bioactivity. The results of the investigations have shown that their predominant constituents are the piper amides which have gradually become a very important class of alkaloids. These amide alkaloids have been demonstrated over the decades to possess very interesting broad spectrum bioactivities that can be harnessed for use in agriculture as pesticides and in medicine as drug leads.

Of great significance is their potential as universal enhancers for insecticidal activity as synergists, and for food and drug utilisation by mammals. Finally, their biogenesis, isolation procedures, and laboratory syntheses fall within the general patterns for other natural products and general organic compounds in Organic Chemistry. Thus, they are readily accessible as natural and synthetic products. As a result of the important bioactivities of the species and their constituent amides, the Piper spp. can therefore be cultivated for large-scale use and this can boost the economy of the developing countries as cheap biopesticides and phytomedicines.

\section{References}

Addae-Mensah, I., Torto, F. G., \& Baxter, I. (1976). Wisanine, A Novel Alkaloid from the Roots of Piper guineense. Tetrahedron Letters, 35, 3049-3050. http://dx.doi.org/10.1016/0040-4039(76)80066-4

Agrawal, A. K., Rao, C. V., Sairam, K., Joshi, V. K., \& Goel, R. K. (2000). Effect of Piper longum Linn., Zingiber officianalis Linn. and Ferula species on gastric ulceration and secretion in rats. Indian J. Exp. Biol., 28(10), 994-998. Retrieved from http://www.ncbi.nlm.nih.gov./pubmed/11324171

Ahn, J. W., Ahn, M. J., Zee, O. P., Kim, E. J., Lee, S. G., Kim, H. J., \& Kubo, I. (1992). Piperidine Alkaloids From Piper retrofractum fruits. Phytochemistry, 31, 3609-3612. http://dx.doi.org/10.1016/0031-9422(92)83736-I

Bajad, S., Singla, A. K., \& Bedi, K. L. (2002). Liquid Chromatographic Method for Determination of Piperine in Rat Plasma: Application to Pharmokinetics. J. Chromatogr. B Biomed. Sci. Appl., 776, 245-249. http://dx.doi.org/10.1016/S1570-0232(02)00352-5

Banerji, A., \& Ghosh, P. C. (1973). Sylvatine, A New Alkamide From Piper sylvaticum ROXB (Piperaceae). Tetrahedron, 29, 977-979. http://dx.doi.org/10.1016/0040-4020(73)80048-1

Batista-Pereira, L. G., Castral, T. C., da Silva, M. T., Amaral, B. R., Fernandes, J. B., Vieira, P. C., ... Correa, A. G. (2006). Insecticidal Activity of Synthetic Amides on Spodoptera frugiperda. Z. Naturforsch, 61(C), 196-202. Retrieved from http://www.ncbi.nlm.nih.gov/pubmed/16729577 
Bezerra, D. P., Pessoa, C., de Moraes, M. O., Silveira, E. R., Lima, M. A., Elmiro, F. J., \& Costa-Lotufo, L. V. (2005). Antiproliferative Effects of Two Amides, Piperine and Piplartine, from Piper Species. Z. Naturforsch., 60(C), 539-543. Retrieved from http://www.ncbi.nlm.nih.gov/pubmed/16163826

Bhardwaj, R. K., Glaesser, H., Becquemont, L., Klotz, U., Gupta, S. K., \& Fromm, M. F. (2002). Piperine, A Major Constituent of Black Pepper Inhibits Human P-glycoprotein and CYP3A4. J. Pharmacol Exp. Ther. 302, 645-650. http://dx.doi.org/10.1124/jpet.102.034728

Blade, R. J. (1990). Some Aspects of Synthesis and Structure-Activity in Insecticidal Lipid Amides. Recent Advances in the Chemistry of Insect Control. 1 (pp. 151-169). Whitstable: RSC.

Catchpole, O. J., Grey, J. B., Perry, N. B., Burgess, E. J., Redmond, W. A., \& Porter, N. G. (2003). Extraction of Chilli, Black Pepper and Ginger with Near-critical CO2, Propane, and Dimethyl ether: Analysis of the Extracts by Quantitative Nuclear Magnetic Resonance. J. Agric. Food Chem., 51, 4853-4860. http://dx.doi.org/10.1021/jf0301246

Chatterjee, A., \& Dutta, C. P. (1967). Alkaloids of Piper longum Linn-1. Structure and Synthesis of $\begin{array}{llll}\text { Piperlongumine } \text { and } & \text { Piperlonguminine. }\end{array}$ http://dx.doi.org/10.1016/S0040-4020(01)82575-8

Davis, J. B., Jackman, L. M., Siddons, P. T., \& Weedon, B. C. L. (1966). Carotenoids and related compounds. Part XV. The structure and synthesis of phytoene, phytofluene, $\zeta$-carotene, and neurosporene. J. Chem. Soc. (C): Organic, 2154-2165. http://dx.doi.org/10.1039/j39660002154

De Araújo-Júnior J. X., Ribeiro, E. A. N., da Silva, S. A. S., da Costa, C. D. F., Alexandre-Moreira, M. S., Santos, B. V. O., ... de Medeiros, I. A. (2011). Cardiovascular Effects of Two Amides (Piperine and Piperdardine) Isolated From Piper tuberculatum Jacq. Emir. J. Food Agric., 23(3), 265-274. Retrieved from http://www.ejfa.info/article/viewFile/7202/3702

De Paula, V. F., Barbosa L. C. de A., Demuner, A. J., Pilo-Veloso, D., \& Picanço, M. C. (2000). Synthesis and Insecticidal Activity of New Amide Derivatives of Piperine. Pest Manag Sci., 56, 168-174. http://dx.doi.org/10.1002/(SICI)1526-4998(200002)56:2<168::AID-PS110>3.0.CO;2-H

Dev, S., \& Koul, O. (1997). Insecticides of Natural Origin. Amsterdam: Hardwood Academic Publishers.

Dewick, P. M. (2009). Medicinal Natural Products-A Biosynthetic Approach (3rd ed., pp. 21, 147-153, 166-169, 326-328). United Kingdom: John Wiley \& Sons Ltd. http://dx.doi.org/10.1002/9780470742761

Dyer, L. A., Dodson, C. D., Stireman III, J. O., Tobler, M. A., Smilanich, A. M., Fincher, R. M., \& Letourneau, D. K. (2003). Synergistic Effects Of Three Piper Amides On Generalist And Specialist Herbivores. Journal of Chemical Ecolog., 29(11), 2499-2514. http://dx.doi.org/10.1023/A:1026310001958

Elliott, M., Farnham, A. W., Janes, N. F., Johnson, D. M., \& Pulman, D. A. (1987). Synthesis and Insecticidal Activity of Lipophilic Amides. Part 1: Introductory Survey, and Discovery of An Active Synthetic Compound. Pestic. Sci., 18, 191-201. http://dx.doi.org/10.1002/ps.2780180305

Finar, I. L. (1975). Organic Chemistry: Stereochemistry and the Chemistry of Natural Products (5th ed., pp. 716-717). Longman Singapore Publishers (Pte) Limited.

Flores, W. L., Sampaio, L. S. V., Marques, O. M., \& Costa, J. A. (1993). Efeito dos extratos de pimenta do reino e cinamomo e do malation no controle do caruncho Zabrotes subfasciatus (Boheman, 1833). Synthesis and Activity of Amide Derivatives of Piperine em sementes de feijaÄo (Phaseolus vulgarisL) armazenadas. Insecta, 2, 11-22.

Geissmann, T. A., \& Grout, D. H. G. (1969). Organic Chemistry of Secondary Plant Metabolism. Retrieved from http://www.trove.nla.gov.au/work/23632698

Grewe, R., Freist, W., Neumann, H., \& Kersten, S. (1970). Uber die inhaltestoffe des Schwarzen Pfeffers. Chem. Ber., 103, 3752-3770. http://dx.doi.org/10.1002/cber.19701031204

Gutierrez, R. M., Gonzalez, A. M., \& Hoyo-Vadillo, C. (2012). Alkaloids from Piper: A Review of its Phytochemistry and Pharmacology. Mini Rev. Med. Chem. (Epub ahead of print, Dec. 31, 2012).

Gwendoline, C. L. E., Chyi, M. L., Mawardi, R., Khozirah, S., \& Choon, F. J. B. (2010). Pellitorine, a Potential Anti-Cancer Lead Compound against HL60 and MCT-7 Cell Lines and Microbial Transformation of Piperine from Piper nigrum. Molecules, 15, 2398-2404. http://dx.doi.org/10.3390/molecules15042405 
Harborne, J. B. (1964). Biochemistry of Phenolic Compounds. London and New York: Acad. Press. Retrieved from http://trove.nla.gov.au/work/19556792

Ivbijaro, M. F., \& Agbaje, M. (1986). Insecticidal Activities of Piper guineense Schum and Thonn and Capsicum species on the Cowpea Bruchid, Callosobruchus maculatus F. Insect Science and its Applications, 7(4), 521-524. http://dx.doi.org/10.1017/S1742758400009760

Kato, M. J., \& Furlan, M. (2007). Chemistry and Evolution of the Piperaceae. Pure Appl. Chem., 79(4), 529-538. http://dx.doi.org/10.1351/pac200779040529

Khajuria A., Thusu, N., \& Zutshi, U. (2002). Piperine Modulates Permeability Characteristics of Intestine By Inducing Alterations in Membrane Dynamics: Influence on Brush Border Membranes Fluidity, Ultra-structure and Enzyme Kinetics. Phytomedicine, 9(3), 224-231. http://dx.doi.org/10.1078/0944-7113-00114

Khajuria, A., Thusu, N., Zutshi, U., \& Bedi, K. L. (1998). Piperine Modulation of Carcinogen Induced Oxidative Stress in Intestinal Mucosa. Mol. Cell. Biochem., 189, 113-118. http://dx.doi.org/10.1023/A:1006877614411

Kiuchi, F., Nakamura, N., Tsuda, Y., Kondo, K., \& Yoshimura, H. (1988). Studies on Crude Drugs Effective on Visceral Larva Migrants. IV. Isolation and Identification of Larvicidal Principles in Pepper. Chem P. harm Bull., 36, 2452-2465. http://dx.doi.org/10.1248/cpb.36.2452

Klohs, M. W., Keller, F., William, R. E., Teokes, T. M., \& Cronheim, G. E. (1959). Chemical and Pharmacological Investigation of Piper methysticum. J. M. Pharm. Chem., 1, 95-105. http://dx.doi.org/10.1021/jm50002a007

Kulkarni, D., Apte, S. P., Mary, F., \& Sane, R. T. (2001). High Performance Thin Layer Chromatographic Method for the Determination of Piperine From Piper nigrum Linn. Indian Drugs, 38, 323-326.

Langhammer, L. (1971). Piper auritum-An Anatomical-historical Study. Use of Piperaceae in Popular MedicineA Comparative Anatomical-Historical Study. Planta Medica, 19(1), 63-70.

Lee S. W., Rho, M. C., Park, H. R., Choi, J. H., Kang, J. Y., Lee, J. W., ... Kim, Y. K. (2006). Inhibition of Diacylglycerol Acyltransferase by Alkamides Isolated From the Fruits of Piper longum and Piper nigrum. J. Agric. Food Chem., 54(26), 9759-9763. http://dx.doi.org/10.1021/jf061402e

Lee, S. G., \& Burt, P. E. (1988). Neurotoxic Actions of a Lipid Amide on the Cockroach Nerve cord and on Locust Somata maintained in Short-term Culture: a Novel Preparation for the Study of $\mathrm{Na}^{+}$Channel Pharmacology. Pesticide Sci., 24, 189-191.

Loder, J. W., Moorhouse, A., \& Russell, E. B. (1969). Tumor-Inhibiting Plants.Amides of Piper novae-Holliandae (Piperaceae). Aust. J. Chem., 22, 1531-1538. http://dx.doi.org/10.1071/CH9691531

McCalla, D. R., \& Neish, A. C. (1959). Metabolism of Phenylpropanoid Compounds in Salvia. II. Biosynthesis of Phenolic Cinnamic Acids. Cana. J. Biochem. Physiol., 17, 537-547. http://dx.doi.org/10.1139/o59-057

Mittal, R., \& Gupta, R. L. (2000). In Vitro Antioxidant Activity of Piperine. Methods Find. Exp. Clin. Pharmacol., 22, 271-274. http://dx.doi.org/10.1358/mf.2000.22.5.796644

Miyakado, M., \& Yoshiok, H. (1979). The Piperaceae Amides II: Synthesis of Pipercide, A New Insecticidal Amide from Piper nigrum L. Agric. Biol. Chem., 43(11), 2413-2415. http://dx.doi.org/10.1271/bbb1961.43.2413

Miyakado, M., Nakayama, I., \& Ohno, N. (1989). Insecticidal Unsaturated Isobutylamides. In J. T. Arnason, B. J. R. Philogene, \& P. Morad (Eds., pp. 173-187), Insecticides of Plant Origin. New York: Maple Press. Retrieved from http://www.pubs.acs.org/isbn/9780841215696

Miyakado, M., Nakayama, I., \& Ohno, N. (1989). Insecticidal Unsaturated Isobutyl amides. From Natural Products to Agrochemical Leads. Am. Chem. Soc. Symp. Ser., 387, 173-187. http://dx.doi.org/10.1021/bk-1989-0387

Miyakado, M., Nakayama, I., Inoue, M., Hatakoshi, M., \& Ohno, N. (1985). Chemistry and Insecticidal Activities of Piperaceae Amides and Their Synthetic Analogues, The Piperaceae Amides (Part 6). J. Pestic. Sci, 10, 11-17. http://dx.doi.org/10.1584/jpestics.10.11 
Miyakado, M., Nakayama, I., Yoshioka, H., \& Nakatan, N. (1979). The Piperaceae Amides. II: Structure of Pipercide, A New Insecticidal Amide from Piper nigrum L. Agric. Biol. Chem., 43(7), 1609-1611. http://dx.doi.org/10.1271/bbb1961.43.1609

Morandim, A. A., Bergamo, D. C. B., Kato, M. J., Cavalheiro, A. J., Bolzani, V. S., \& Furlan, M. (2005). Phytochem. Anal., 16, 282-286. http://dx.doi.org/10.1002/pca.843

Morrison, R. T., \& Boyd, R. N. (2006). Organic Chemistry (6th ed., pp. 323, 390, 392). New Delhi: Prentice-Hall of India Private Limited.

Ogobegwu, C. O. (1973). Studies of the Insecticidal Activities of Some Nigerian Plant Extracts (Dissertation for the Award of B.Sc. Agric. Biology, University of Ibadan, Nigeria).

Okogun, J. I., \& Ekong, D. E. U. (1974). Extracts From the Fruits of Piper guineense Schum and Thonn. J. Chem. Soc., 2195-2198.

Okogun, J. I., Sodengam, B. L., \& Kimbu, S. F. (1977). New Amides From the Extracts of Piper guineense. Phytochemistry, 16, 1295. http://dx.doi.org/10.1016/S0031-9422(00)94379-6

Okwute, S. K. (1978). Synthesis of Amides From Piper guineense, Schum and Thonn: The Case of Insecticidal guineensine (A Thesis Submitted in Partial Fulfilment of the Requirements for the Award the Degree of Doctor of Philosophy (Ph.D) of the University of Ibadan, Nigeria, Department of Chemistry).

Okwute, S. K. (1992). Plant-derived Pesticidal and Antimicrobial Agents for Use in Agriculture: A Review of Phytochemical and Biological Studies on Some Nigerian Plants. Journal of Agric, Science and Technology, 2(1), 62-70.

Okwute, S. K. (2012). Plants as Potential Sources of Pesticidal Agents: A Review. In: Pesticides-Advances in Chemical and Botanical Pesticides (Chapter 9, pp. 207-232). Delhi, India: InTech. http://dx.doi.org/10.5772/46225

Okwute, S. K., Okogun, J. I., \& Okorie, D. A. (1984). Revised Structure and Synthesis of Piperolein Acids, Guineensine and Wisanine from Piper guineense. Tetrahedron, 40(13), 2541-2545. http://dx.doi.org/10.1016/S0040-4020(01)83507-9

Ottea, J. A., Payne, G. T., \& Soderlund, D. M. (1990). Action of Insecticidal N-alkylamides at Site 2 of the Voltage-sensitive Sodium Channel. J Agric Food Chem., 38, 1724-1728. http://dx.doi.org/10.1021/jf00098a021

Park, K. II (2012). Larvicidal Activity of Constituents Identified in P. Nigrum L. Fruit Against the Diamondbark Moth, Platella xylostella. Kor. J. Appl. Entomol., 15(2), 149-152.

Parmar, V. S., Jain, S. C., Bisht, K. S., Jain, R., Taneja, P., Jha, A., ... Boll, P. (1997). Phytochemistry of the Genus Piper. Phytochemistry, 46, 597-673. http://dx.doi.org/10.1016/S0031-9422(97)00328-2

Patra, A., \& Ghosh, A. (1974). Amides of Piper chaba. Phytochem, 13, 2889-90. http://dx.doi.org/10.1016/0031-9422(74)80272-4

Pedersen, M. E., Metzler, B., Stafford, G. I., Van Staden, J., Jäger, A. K., \& Rasmussen, H. B. (2009). Amides from Piper capense with CNS activity. Molecules, 14(9), 3833-3843. http://dx.doi.org/10.3390/molecules 14093833

Piyachaturawat, P., Glinsukon, T., \& Toskulkao, C. (1983). Acute and Sub-acute Toxicity of Piperine in Mice, Rat and Hamsters. Toxic Lett., 16, 351-359. http://dx.doi.org/10.1016/0378-4274(83)90198-4

Pridgeon, J. W., Meepagala, K. M., Becnel, J. J., Clark, G. G., Peretra, M. R., \& Linthicum, K. J. (2007). Structure-Activity Relationships of 33 Piperidines as Toxicants against Female Adults of Aedes aegypti

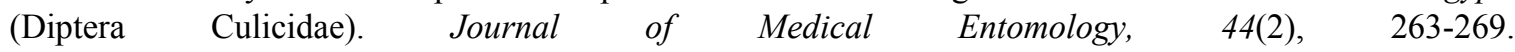
http://dx.doi.org/10.1603/0022-2585(2007)44[263:SROPAT]2.0.CO;2

Raman, G., \& Gaikar, V. J. (2002). Microwave-assisted Extraction of Piperine from Piper nigrum. Ind. Eng. Chem. Res., 41, 2521-2528. http://dx.doi.org/10.1021/ie010359b

Reen, R. K., \& Singh, J. (1991). In Vitro and In Vivo Inhibition of Pulmunary Cytochrome P450 Activities by Piperine, a Major Ingredient of Piper Species. Ind. J. Exp. Biol., 29, 568-573. Retrieved from http://www.ncbi.nlm.nih.gov/pubmed/1889831 
Sawangjaroen, N., Sawangjaroen, K., \& Poonpanang, P. (2004). Effects of P. longum Fruit, P. Sarmentosum Root and Quercus infectoria Nut Gall on Caecal Amoebiosis in Mice. J. Ethnopharmacol., 91(2-3), 357-360. http://dx.doi.org/10.1016/j.jep.2004.01.014

Scott, I. M., Jensen, H., Scott, J. G., Isman, M. B., Arnason, J. T., \& Philogène, B. J. R. (2003). Botanical Insecticides for Controlling Agricultural Pests: Piper amides and the Colorado Potato Beetle Leptinotarsa decemlineata Say (Coleoptera: Chrysomelidae). Archives of Insect Biochemistry and Physiolog, 212-225. http://dx.doi.org/10.1002/arch.10118

Scott, I. M., Puniani, E., Durst, T., Phelps, D., Merali, S., Assabgui, R. A., ... Arnason, J. T. (2002). Insecticidal Activity of Piper tuberculatum Jacq. Extracts: Synergistic Interaction of Piperamides. Agric. For. Entomol., 4, 137-144. http://dx.doi.org/10.1046/j.1461-9563.2002.00137.x

Scott, I. M., Puniani, E., Jensen, H., Livesey, J. F., Poveda, L., Nchez-Vindas, P. S., ... Arnaso, J. T. (2005). Analysis of Piperaceae Germplasm by HPLC and LCMS: A Method for Isolating and Identifying Unsaturated Amides from Piper spp. Extracts. Ontario Ministry of Science and Technology funded research. Retrieved from http://www.aseanbiodiversity.info/abstract/51005573.pdf

Scott, W. P., \& McKibben, G. H. (1978). Toxicity of Black Pepper Extract to Boll Weevils. J. Econ. Entomol., 71, 343-344.

Sharma, R. S., Rajalakshmi, M., Sharma, R. S., \& Jeyaraj, D. A. (2001). Current Status of Fertility Control Methods in India. J. Biosc., 26(4), 391-405. http://dx.doi.org/10.1007/BF02704741

Shorygin, P. A., Simanovskaya, A. A., \& Bgdanova A. V. (1938). Synthesis of Piperonal from Pyrocatechol. $J$. Gen. Chem. (USSR), 8, 975-980.

Sighamony, S., Anees, I., Chanrakala, T., \& Osmani, Z. (1986). Efficacy of Certain Indignous Plant Products as Grain Protectants against Sitophilus oryzae (L.) and Rhyzopertha dominica (F.). J. Stored Prod Res, 22, 21-22. http://dx.doi.org/10.1016/0022-474X(86)90042-1

Singh, A., \& Rao, A. R. (1993). Evaluation of the Modulatory Influence of Black Pepper (Piper nigrum, L.) on the Hepatic Detoxication System. Cancer Lett., 72, 5-9. http://dx.doi.org/10.1016/0304-3835(93)90003-R

Singh, J., \& Reen, R. K. (1994). Modulation of Constitutive, Benz-[a]anthracene- and Phenobarbital-inducible Cytochromes P450 Activities in Rat Hepatoma H4IIEC3/G-Cells by Piperine. Curr Sci., 66, 365-369. Retrieved from http://www.ias.ac.in/j_archive/currsci/66/5/365-369/viewpage

Singh, J., Dhar, K. L., \& Atal, C. K. (1969). Studies on the Genus Piper-IX.Structure of Trichostachine, an Alkaloid from Piper trichostachyon. Tet. Letts., 56, 4975-4978. http://dx.doi.org/10.1016/S0040-4039(01)88862-6

Su, H. C. F. (1977). Insecticidal Properties of Black Pepper to Rice Weevils and Cowpea Weevils. J. Econ Entomol., 70, 18-21. http://www.fao.org/docrep/006/Q4165E/Q4165E03.htm\#ch3.1

Su, H. C. F., \& Horvat, R. (1981). Isolation, Identification, and Insecticidal Properties of Piper nigrum Amides. J. Agric. Food Chem., 29, 115-118. http://dx.doi.org/10.1021/jf00103a029

Sunila, E. S., \& Kuttan, G. (2004). Immunomodulatory and Antitumor Activity of Piper longum Linn. And Piperine. J. Ethnopharmaco., 90(2-3), 339-346. http://dx.doi.org/10.1016/j.jep.2003.10.016

Sunkara, G., \& Mada, S. R., \& Vobalaboina, V. (2001) Pharmokinetics and Tissue Distribution of Piperine in Animals after i.v. Bolus Administration. Pharmazie., 56, 640-642. Retrieved from http://www.ncbi.nlm.nih.gov/pubmed/11534342

Synerholm, M. E., Hartzell, A., \& Arthur, J. M. (1945). Derivatives of Piperic acid and their Toxicities towards Houseflies. Contrib Boyce Thompson Inst, 13, 433-442.

Vikash, C., Shalini, T., Verma N. K., Singh, D. P., Chaudhary, S. K., \& Asha, R. (2011). Piper betel: Phytochemistry, Traditional Use and Pharmacological Activity-A Review. International Journal of Pharmacological Research and Development, 4(4), 216-223. Retrieved from http://www.ijprd.com/June_12_Issue.html

Viswanathan, N., Balakrishnan, V., Joshi, B. S., \& von Philipsborn, W. (1975). Piperaceae Alkaloids: Part III. Synthesis of N-isobutyl-11-(3,4-methylenedioxyphenyl)-undeca-2,4,6-trans, trans, trans-trienoic amide and N-isobutyl-11-(3,4-methylenedioxyphenyl)-undeca-2,8,10-trans, trans, trans-trienoic amide (piperstachine). Helv. Chim. Acta, 58, 2026-2035. http://dx.doi.org/10.1002/hlca.19750580717 


\section{Copyrights}

Copyright for this article is retained by the author(s), with first publication rights granted to the journal.

This is an open-access article distributed under the terms and conditions of the Creative Commons Attribution license (http://creativecommons.org/licenses/by/3.0/). 